\title{
DESCRIPTION AND CONTROLS ON DISTRIBUTION OF PLEISTOCENE VERTEBRATE FOSSILS FROM THE CENTRAL AND SOUTHERN SECTORS OF THE COASTAL PLAIN OF RIO GRANDE DO SUL, BRAZIL
}

\author{
ERICK A. CRUZ, SÉRGIO R. DILLENBURG \\ Programa de Pós-Graduação em Geociências, CECO-UFRGS, 9500, 91501-970, Porto Alegre, RS, Brazil. \\ erickantal@gmail.com, sergio.dillenburg@ufrgs.br \\ FRANCISCO S. BUCHMANN \\ Laboratório de Estratigrafia e Paleontologia, UNESP-Litoral Paulista, s/n, 11330-900, São Vicente, SP, Brazil. \\ paleonchico@yahoo.com.br
}

\begin{abstract}
The objective of the present work is to compare the presence of Pleistocene vertebrate fossils from the central and southern sectors of the Coastal Plain of Rio Grande do Sul, quantifying and qualifying the taphonomy, and taxonomic group and skeletal remains representativeness. A total of 2,820 fossils was collected, among them $95 \%$ were collected in the southern sector and 5\% in the central sector. In both sectors were identified two populations of bioclasts: non-identified fossils $(85 \%)$ and identified fossils (15\%). The same taxonomic groups and skeletal remains were identified in both sectors, except for some due to the different amount of fossils collected. The two populations of bioclasts identified represent greater ( $85 \%$ non-identified) or less (15\% identified) reworking by waves. The hypothesis for the different amount of fossils collected is the availability of fossils on the shoreface and inner continental shelf. The presence of several submerged sedimentary rocks and records of paleolagoons and paleochannels on the shoreface and inner continental shelf of the southern sector indicates probably the source-areas where the skeletal remains were once fossilized and now are being eroded.
\end{abstract}

Key words: megafauna, taphonomy, Quaternary, coastal evolution.

RESUMO - O objetivo do presente trabalho é comparar a presença de fósseis de vertebrados pleistocênicos encontrados nos setores central e sul da Planície Costeira do Rio Grande do Sul, quantificando e qualificando-os quanto à tafonomia, e representatividade dos grupos taxonômicos e restos esqueletais. Foi coletado um total de 2.820 fósseis, dentre os quais $95 \%$ foram coletados no setor sul e 5\% no setor central. Em ambos os setores foram identificadas duas populações de bioclastos: fósseis não-identificados (85\%) e fósseis identificados (15\%). Foram encontrados os mesmos grupos taxonômicos e restos esqueletais para ambos os setores, com exceção de alguns devido à diferença na quantidade de fósseis coletada. As duas populações de bioclastos identificadas estão relacionadas ao maior ( $85 \%$ não-identificável) ou menor (15\% identificável) retrabalhamento pelas ondas. A principal hipótese para a diferença na quantidade de fósseis coletada é a disponibilidade de fósseis na antepraia e plataforma interna. A presença de vários parcéis e registros de paleolagunas e paleocanais fluviais na antepraia e plataforma interna do setor sul indica, provavelmente, as áreas-fonte de onde os restos esqueletais foram uma vez fossilizados e agora estão sendo erodidos.

Palavras-chave: megafauna, tafonomia, Quaternário, evolução costeira.

\section{INTRODUCTION}

The presence of fossils of terrestrial mammals in the Coastal Plain of Rio Grande do Sul (CPRS) is well known since taxonomic works of Paula Couto $(1975,1979)$ and Soliani Jr. \& Jost (1974). Later studies on such fossils have focused on their location and distribution (Buchmann, 1994, 2002; Lopes et al., 2009; Lima \& Buchmann, 2005; Lopes \& Buchmann, 2010; Lopes \& Pereira, 2010, 2013; Cruz et al., 2015a,b), their taphonomy (Caron, 2004; Lopes et al., 2001, 2008; Cruz \& Buchmann, 2013a,b; Lopes \& Ferigolo, 2015), ages (Lopes et al., 2010, 2014a,b), paleoenvironmental interpretations (Lopes et al., 2013) and biostratigraphy (Lopes, 2013).
The presence of terrestrial fossils in a modern marine environment is attributed to the sea-level oscillations during the Quaternary. During glacial periods, large areas of the continental shelves around the world were exposed and occupied by terrestrial environments. Afterwards, these areas were flooded and reworked by the sea-level rise during interglacial periods (Lopes \& Buchmann, 2010; Lopes et al., 2010). The fossil concentrations on the inner continental shelf, at depths between 0 and $20 \mathrm{~m}$, are being eroded by storm waves, during autumn and winter, and transported to the beach (Figueiredo Jr., 1975; Buchmann, 2002). The fossils are found disarticulated, exhibiting signs of post mortem breakage and abrasion due to reworking by waves (Lopes et al., 2008; Lopes \& Ferigolo, 2015), which complicates the analyses of 
stratigraphy and taphonomy, and also the identification of skeletal structures and taxa (Caron, 2004; Aires \& Lopes, 2012).

The objective of the present work is to compare the presence of Pleistocene vertebrate fossils found in the central and southern sectors of the CPRS, quantifying and qualifying the taphonomy, and taxonomic group and skeletal remains representativeness. The northern sector of the CPRS was not included in this research due to the absence of fossils in the sector (Buchmann, 2002).

\section{STUDY AREA}

The study area of the present work is located in South America, Brazil, in the Coastal Plain of Rio Grande do Sul (CPRS). The central sector comprehends the area between Mostardas and São José do Norte counties and the Patos Lagoon. Within this sector, it is found the Peixe Lagoon National Park, Mostardas lighthouse, Conceição lighthouse and Estreito lighthouse. The southern sector comprehends the area between Rio Grande and Santa Vitória do Palmar counties and the Mangueira Lake. Within this sector, it is found the
Sarita lighthouse, Verga lighthouse, Albardão lighthouse and Concheiros beach (Figure 1).

According to Dillenburg et al. (2009), both sectors are situated in the southern part of the two large convex projections of the coast, and hence under the influence of higher wave height/energy and angle of wave attack (Lima et al., 2001; Martinho, 2008; Cecilio, 2015). Moreover, the sectors are composed of transgressive barriers which were formed by long-term erosion, forced by the local deficit of sediment budget (Dillenburg et al., 2000, 2003, 2009; Caron et al., 2007, 2011; Lima et al., 2013).

The CPRS is $620 \mathrm{~km}$ long and has a barrier coast oriented NE-SW (Buchmann et al., 2009). Between the Neogene and Quaternary, the morphology of the CPRS was affected by glacioeustatic oscillations, which led to the formation of two major depositional systems: the Alluvial Fans System and the Barrier-Lagoon System (Figure 1) (Villwock, 1984; Villwock \& Tomazelli, 1995; Tomazelli \& Villwock, 1996).

The Barrier-Lagoon System is subdivided into four large barrier-lagoons. Each one was formed by a marine transgression, correlated to Late Pleistocene-Holocene

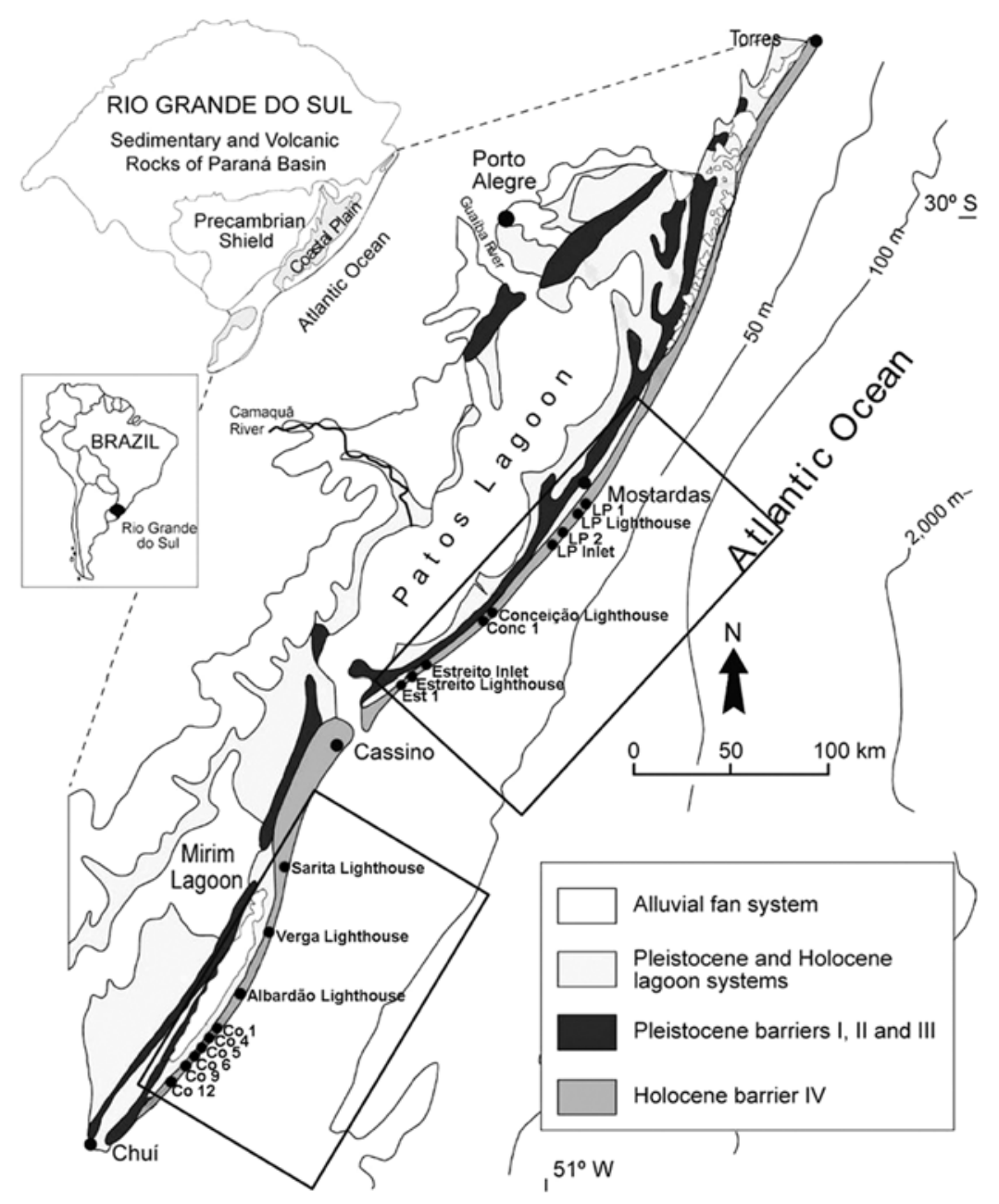

Figure 1. Study area. The geological map of the Coastal Plain of Rio Grande do Sul and its depositional systems: Alluvial Fans System and Barrier-Lagoon System showing the central and southern sectors (rectangles) with its corresponding sampling points (black dots). Notice that both sectors are situated in the two large convex projections of the coast (after Dillenburg et al., 2009). 
interglacial episodes (Tomazelli et al., 2000). Villwock \& Tomazelli (1995) correlated the ages of the barriers with the peaks of the isotopic curve proposed by Imbrie et al. (1984). The Pleistocene barriers I, II and III were correlate to the isotopic stages 11 (400 ka), 9 (325 ka) and 5 (120 ka), respectively, and the Holocene Barrier IV is correlate to the stage 1 (6 ka). Later on, Lopes et al. (2014b) postulated new ages for the Barrier II (220-240 ka, isotopic stage 7e), leaving open the question about the age of the Barrier I.

The central and southern sectors here studied have some particular characteristics concerning the bathymetry of its shoreface and inner continental shelf. The central sector has a steep and continuous slope, with the presence of some submerged sedimentary rocks, and the isobaths are parallel to each other. On the other hand, the southern sector has a smoother and discontinuous slope, with the presence of several submerged sedimentary rocks, and the isobaths are uneven and disorganized, showing several submerged elevations and depressions (Correa, 1990, 1994; Buchmann, 2002). These bathymetric differences also generate wave power differences. The steeper and continuous slope of the central sector increases the wave power while the presence of submerged sedimentary rocks and elevations in the southern sector attenuates the wave power (Cecilio, 2015).

During the Quaternary, especially the last well-known sea-level rise during the Holocene (Martin et al., 1979, 2003; Corrêa, 1990; Angulo \& Lessa 1997; Angulo et al., 1999, 2006), the oscillations of the sea-level played an important role in the reworking of relic sediments present on the shoreface and inner continental shelf of the Rio Grande do Sul. During the sea-level rise, the sedimentary record of the ocean bottom is eroded at least $10 \mathrm{~m}$ (Dillenburg, 1994, 1996), thus exposing and eroding paleolagoons, paleochannels and incised valleys present on the continental shelf (Figure 2) (Corrêa, 1986; Corrêa et al., 1996; Martins et al., 1996; Weschenfelder et al., 2010, 2014; Silva, 2009). After several sea-level oscillations, the skeletal remains of Pleistocene mammals preserved in these fluvial channels and lagoons have been reworked, and nowadays they are transported to the beaches along the coast (Buchmann et al., 1999, 2001b; Buchmann \& Tomazelli, 1999a, 2000, 2003; Lopes et al., 2001, 2010; Lopes \& Buchmann, 2010).

\section{MATERIAL AND METHODS}

A total of 2,820 fossils were collected in eight field works between 2014 (January, April and June) and 2015 (January, May and October). Sampling points were used in each sector of the CPRS: in the central sector, Peixe Lagoon (LP 1, LP 2, LP lighthouse, LP inlet), Conceição (Conc 1, Conceição lighthouse) and Estreito (Est 1, Estreito lighthouse, Estreito inlet); in the southern, Sarita lighthouse, Verga lighthouse, Albardão lighthouse and Concheiros beach (\#1, \#4, \#5, \#6, $\# 9$, \#12) (Figure 1). In each station, the fossils were collected in a radius of $300 \mathrm{~m}$ from the georeferenced waypoint of the station, between the foreshore (Figure 3A) and foredunes (Figure 3B). The collected fossils were washed, dried

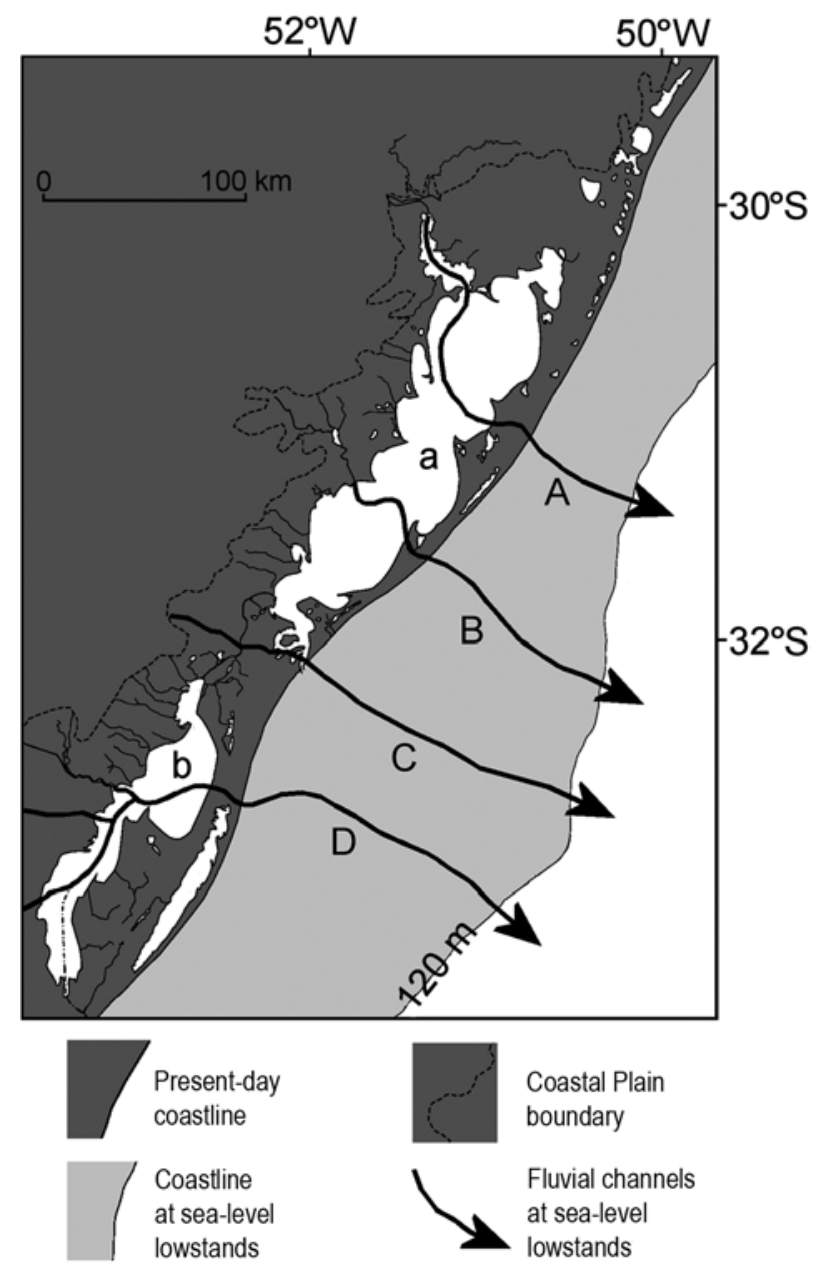

Figure 2. Paleo-drainages patterns on the RS continental shelf during pre-Holocene sea level lowstands, associated to the Patos Lagoon (a) and Mirim Lake (b): A, Guaíba River, B, Camaquã River, C, Piratini River, D, Jaguarão, Tacuari and Cebollati rivers (after Lopes \& Buchmann, 2010).

and sorted in the laboratory. Then they were measured in millimeters with a digital caliper rule. The fossils were classified as non-identified or identified. Non-identified represents skeletal fragments non-identifiable. Identified represents a known taxa or skeletal remain, or both. Each specimen was classified to the lowest taxonomic group. The fossils figured here were deposited in the paleontological collection of the Museu de Ciências Naturais da Fundação Zoobotânica do Rio Grande do Sul (MCN-PV).

\section{RESULTS}

Overall, more fossils were collected in the southern sector (2,689 fossils) than in the central. In both sectors, the nonidentified fossils (approx. 80\%) outnumbered the indentified ones (approx. 20\%). There was also a unimodal trend of bioclasts size in the simple frequency histogram, resulting in a well sorted distribution for both sectors. Bioclasts measuring between $32-64 \mathrm{~mm}$ outnumbered by more than $50 \%$ the other size classes (Figure 4). 


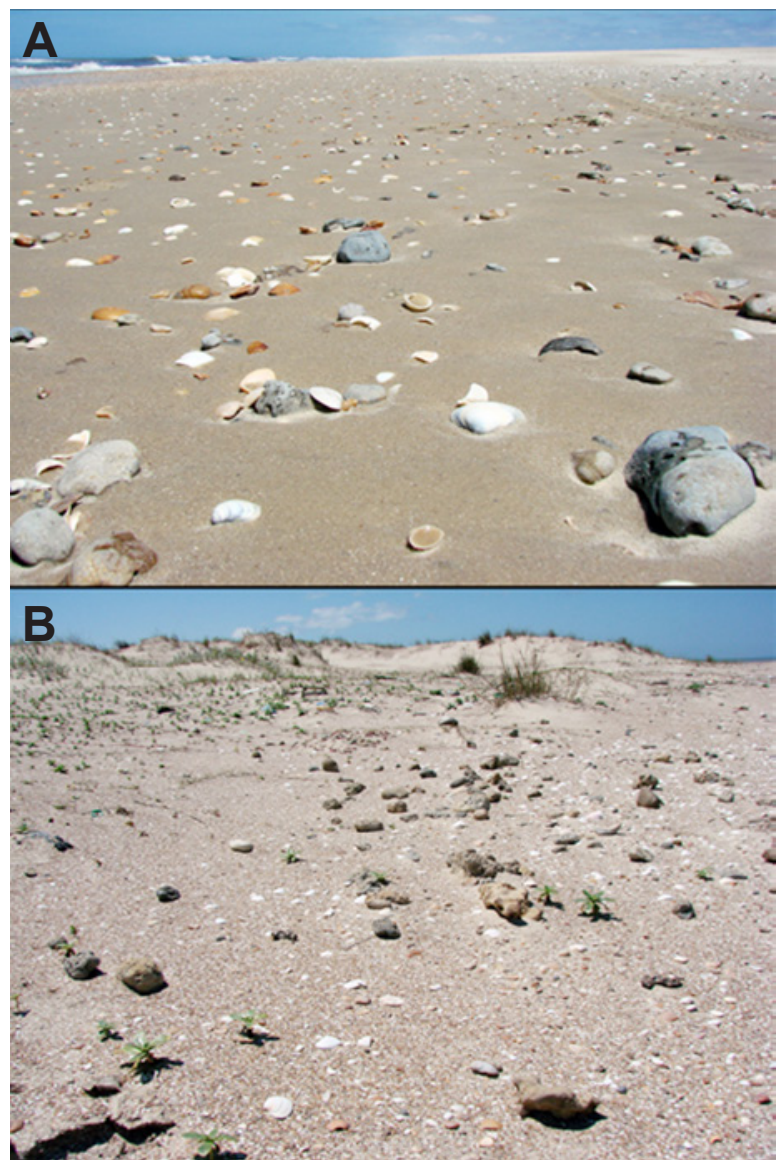

Figure 3. Sampling area of each station. A, fossils found in the foreshore and backshore of the beach; B, fossils found on the foredunes (by Francisco Buchmann).

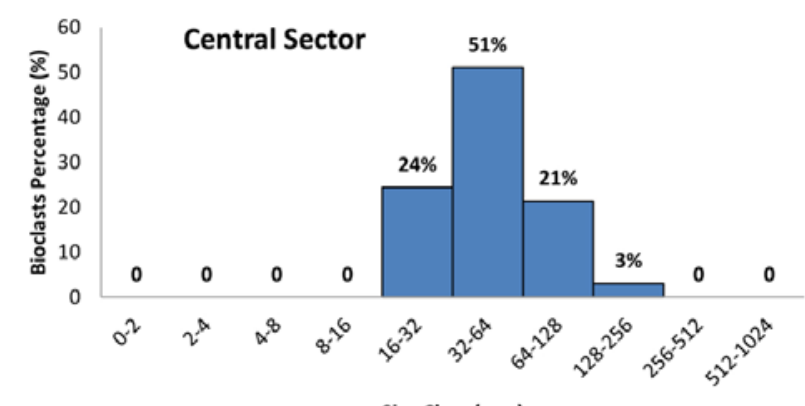

Size Class (mm)

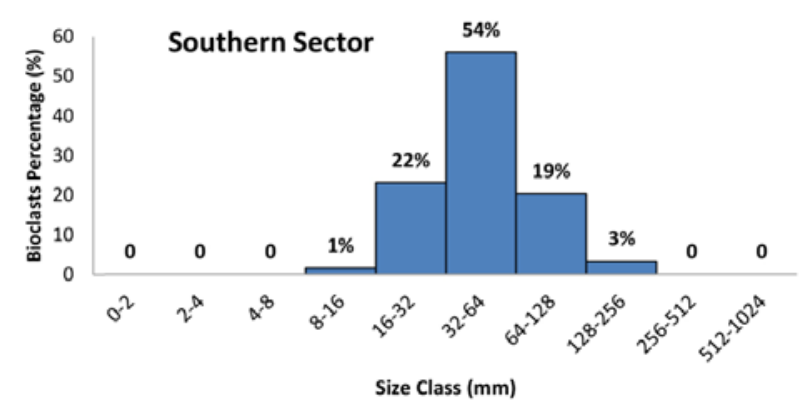

Figure 4. Classification of bioclasts by size. The great amount for both sectors was sizes between 32-64 mm, resulting in a well-sorted pattern and unimodal trend.
The skeletal remains and taxonomic groups represent a mix of terrestrial and marine fauna. No previously undescribed taxon was found. In both sectors, the terrestrial fauna (approx. $70 \%$ ) outnumbered the marine fauna (approx. 30\%). The skeletal remains and taxonomic groups identified in the central sector were also present in the southern, except for teeth of elasmobranchs, equids (Figures 5A-B) and gomphotheriids (Figure 5C); pterygiophores, scales and vertebrae of fishes; intervertebral discs, skulls, tympanic bullae and blowholes of cetaceans; antlers, astragali and teeth of cervids (Figures $5 \mathrm{D}-\mathrm{G})$; and bone fragments of Aves, that were only found in the southern sector.

In the terrestrial fauna, the accessory elements represented by osteoderms of cingulates were the most abundant skeletal remains. Besides accessory elements, cranial elements such as teeth and axial elements such as vertebrae (Figure 6) were also found in abundance. The appendicular elements such as long bones were only found in the southern sector (Figure 7). Among the cingulates, the genera Glyptodon and Panochthus (Glyptodontidae) and Pampatheriidae (Pampatherium) were found in both sectors, except for the genera Holmesina (Pampatheriidae) and Propraopus (Dasypodidae), that were only found in the southern sector (Figure 8).

In the marine fauna, the most common skeletal remain were hyperostotic bones of Sciaenidae indet. (Figure 9A). In the marine mammalian group, a skull of Pontoporia sp. was identified (Figure 9B). The teeth of sharks and rays (Figures 9C-F) were only found in the southern sector always associated with the thick konzentrat-lagerstätte of fossil marine shells, called "Concheiros" (Figure 10), only present in the southern sector. The genus Carcharias taurus (Lamniformes) was the most abundant kind of shark.

The list of the terrestrial and marine taxonomic groups identified for each sector is shown below, with their respective percentage (Tables 1-2). Similarly, the terrestrial and marine skeletal elements identified (Tables 3-4).

\section{DISCUSSION}

\section{Taphonomic aspects}

In each sector of the coastal plain, it was identified two kind of bioclasts population: (i) non-identified fossils (around $80 \%$ ), indicating greater reworking by waves, high degree of fragmentation and loss of diagnostic structures used for identification (Figure 11A); and (ii) identified fossils (around $20 \%$ ), indicating less reworking by waves, low degree of fragmentation and preservation of diagnostic structures used for identification (Figure 11B) (Lopes et al., 2008; Lopes \& Buchmann, 2010; Aires \& Lopes, 2012; Cruz \& Buchmann, $2013 a, b)$. The two bioclasts populations reassure that the submerged fossiliferous deposits along the CPRS have been under the same influence of erosive processes (Dillenburg et al., 2004), wave dynamics (Calliari et al., 1998a,b) and sealevel oscillations during the Quaternary (Buchmann et al., 1999, 2009; Buchmann \& Tomazelli, 1999a, 2003; Lopes \& Buchmann, 2010).

In both sectors there was a selection by bioclasts size. Small and medium (32-64 $\mathrm{mm}$ ) bioclasts are more common 

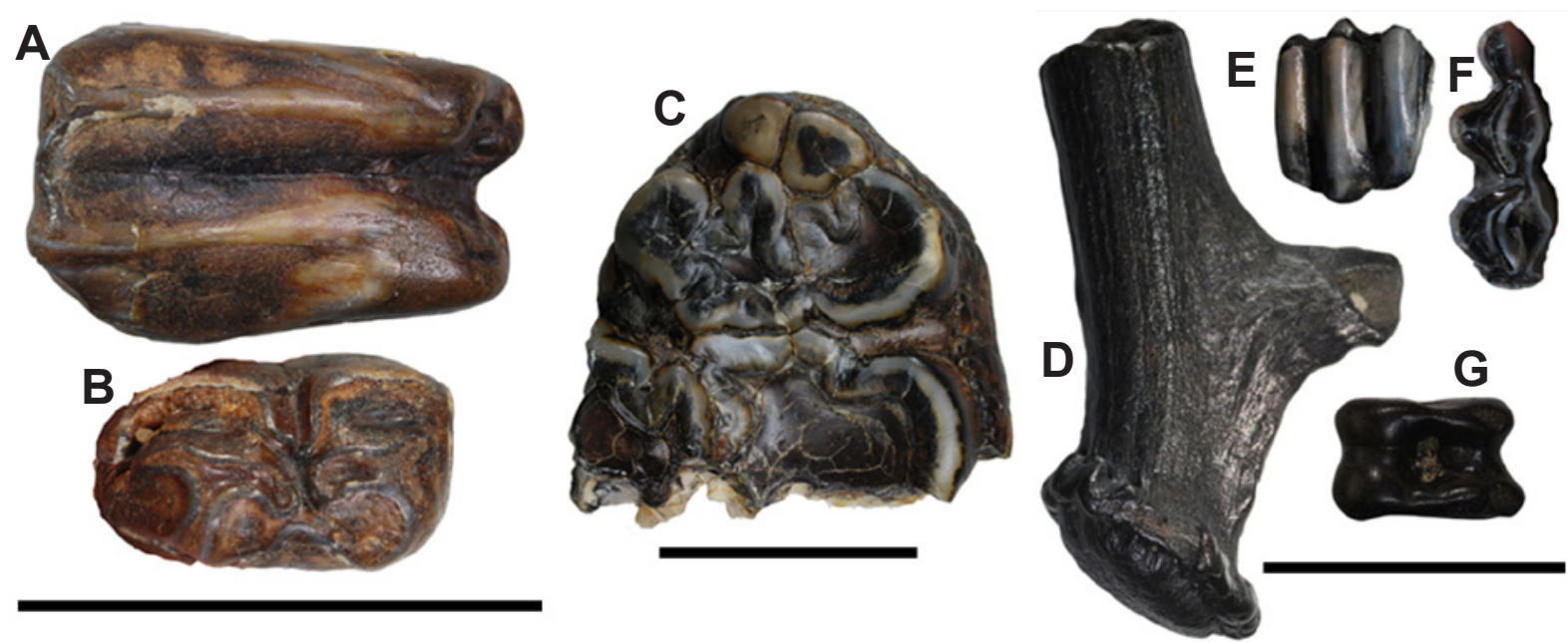

Figure 5. A-G, skeletal remains represented by cranial and dental elements. A-B, tooth of Equus sp. (MCN-PV 36.603), A, lingual view, B, occlusal view. C, partial tooth of gomphotheriid in occlusal view (MCN-PV 36.604). D, antler (MCN-PV 36.605); E-F, cervid tooth (MCN-PV 36.606), E, lingual view, F, occlusal view; G, cervid astragalus (MCN-PV 36.607) (by Erick Cruz). Scale bars $=50 \mathrm{~mm}$.
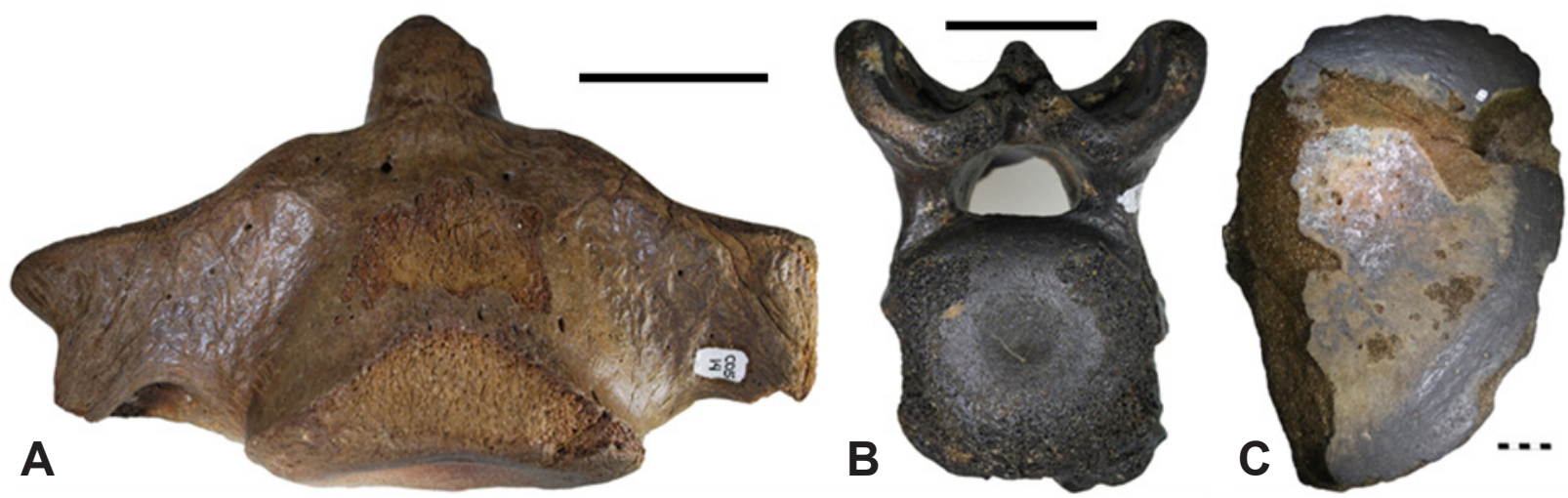

Figure 6. A-C, axial elements represented by vertebrae. A, the second cervical vertebra (MCN-PV 36.608); B, partial vertebra of unidentified taxon (MCN-PV 36.609); C, partial vertebra of cetacean (MCN-PV 36.610) (by Erick Cruz). Scale bars $=50 \mathrm{~mm}$.
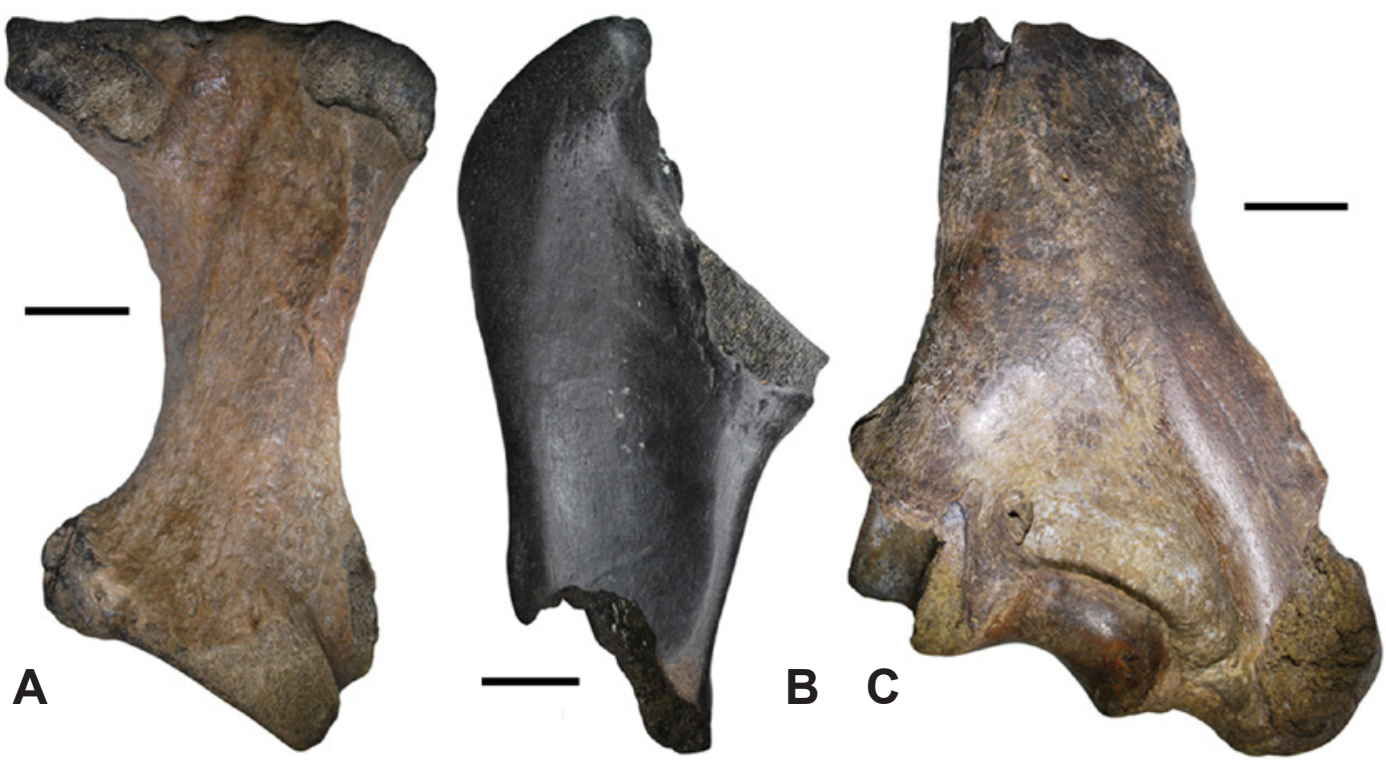

Figure 7. A-C, appendicular elements represented by long bones. A, tibia of Lestodon sp. (MCN-PV 36.611); B, partial ulna of ground sloth (MCN-PV 36.612); C, partial femur of Toxodon sp. (MCN-PV 36.613) (by Erick Cruz). Scale bars $=50 \mathrm{~mm}$. 

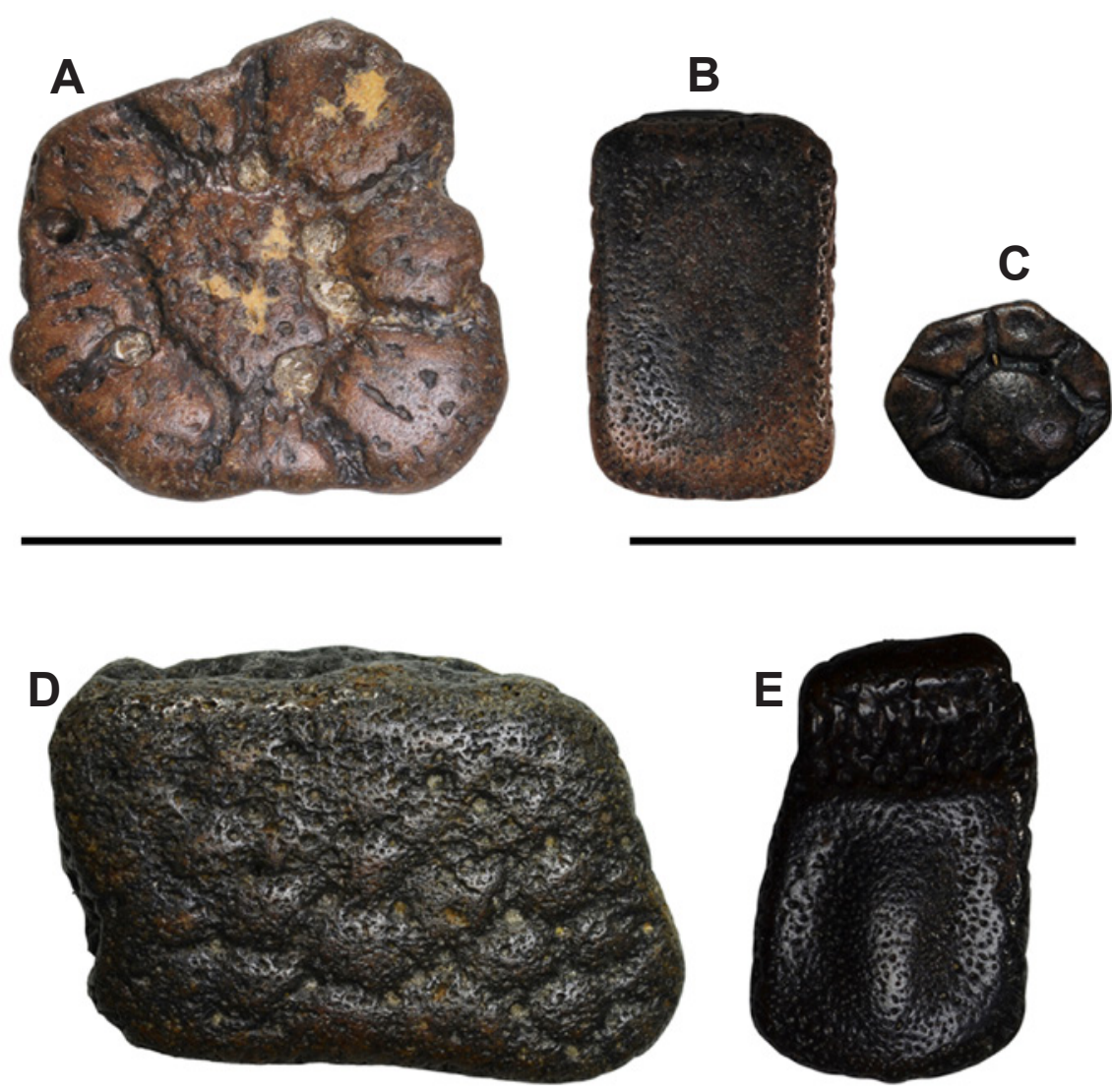

Figure 8. A-E, accessory elements represented by osteoderms of cingulates. A, Glyptodon (MCN-PV 36.614); B, Pampatherium (MCN-PV 36.615); C, Propraopus (MCN-PV 36.616); D, Panochthus (MCN-PV 36.617); E, Holmesina (MCN-PV 36.618) (by Erick Cruz). Scale bars = 50 mm.

than large, since it is easier to be transported and requires lower wave energy. Yet, the more it is transported, the more it is fragmented, and the more it loses diagnostic structures used for identification (Lopes et al., 2008; Lopes \& Buchmann, 2010; Aires \& Lopes, 2012). That is why the majority of the fossils (80\%) are non-identifiable, very fragmented and small.

There was a unimodal trend of bioclasts size in the simple frequency histogram, resulting in a well-sorted distribution in both sectors. Bioclasts measuring between 32-64 mm outnumbered by more than $50 \%$ the other size classes (Figure 4). On the other hand, previous works from Caron (2004) and Lopes et al. (2008) have shown a bimodal trend of bioclasts size in the southern sector, more specifically in Concheiros beach, resulting in a poorly sorted distribution that probably indicates a shorter distance from the source-area. Therefore, the new results from the present work show a change in the bioclasts size distribution. It probably indicates that the availability of the fossils has also changed. Fossils that were once prone to erosion from the source-area and remained available to be transported to the beach are no longer being eroded and/or transported to the beach, indicating, perhaps, the source-area starvation. Nowadays, the remaining available fossils are being constantly fragmented by waves into smaller sizes. This issue will be discussed further in another article.

The largest amount of fossil was collected in the southern sector (2,689 fossils), representing $95 \%$ of the total, while in the central sector were collected 131 fossils, representing only $5 \%$. The main hypothesis for this difference is the availability of fossils on the shoreface and inner continental shelf. The central and southern sectors have certain similarities as shown above in the study area section, but their bathymetry and seafloor characteristics are totally different. The presence of several submerged sedimentary rocks and submerged elevations and depressions on the shoreface and inner continental shelf of the southern sector indicates probably the presence of source-areas where the fossils are eroded from (Buchmann et al., 1999, 2001b; Buchmann \& Tomazelli, 1999a, 2000, 2001, 2003).

During glacial periods, when the sea-level was lower than today, terrestrial environments such as fluvial channels and lagoons were present in the exposed continental shelf (Corrêa, 1986, 1990; Corrêa et al., 1996; Martins et al., 1996; Weschenfelder et al., 2010, 2014; Silva, 2009), which would have favored the preservation of mammals' skeletal remains. Afterwards, during interglacial periods (sea-level highstands), the continental shelf was flooded and reworked by the sealevel rise. After several sea-level oscillations, the skeletal remains of Pleistocene mammals preserved in these fluvial channels and lagoons (source-areas) have been reworked, and nowadays they are being transported to the beaches along the coast (Buchmann et al., 1999, 2001b; Buchmann \& Tomazelli, 1999a, 2000, 2003; Lopes et al., 2001, 2010; 

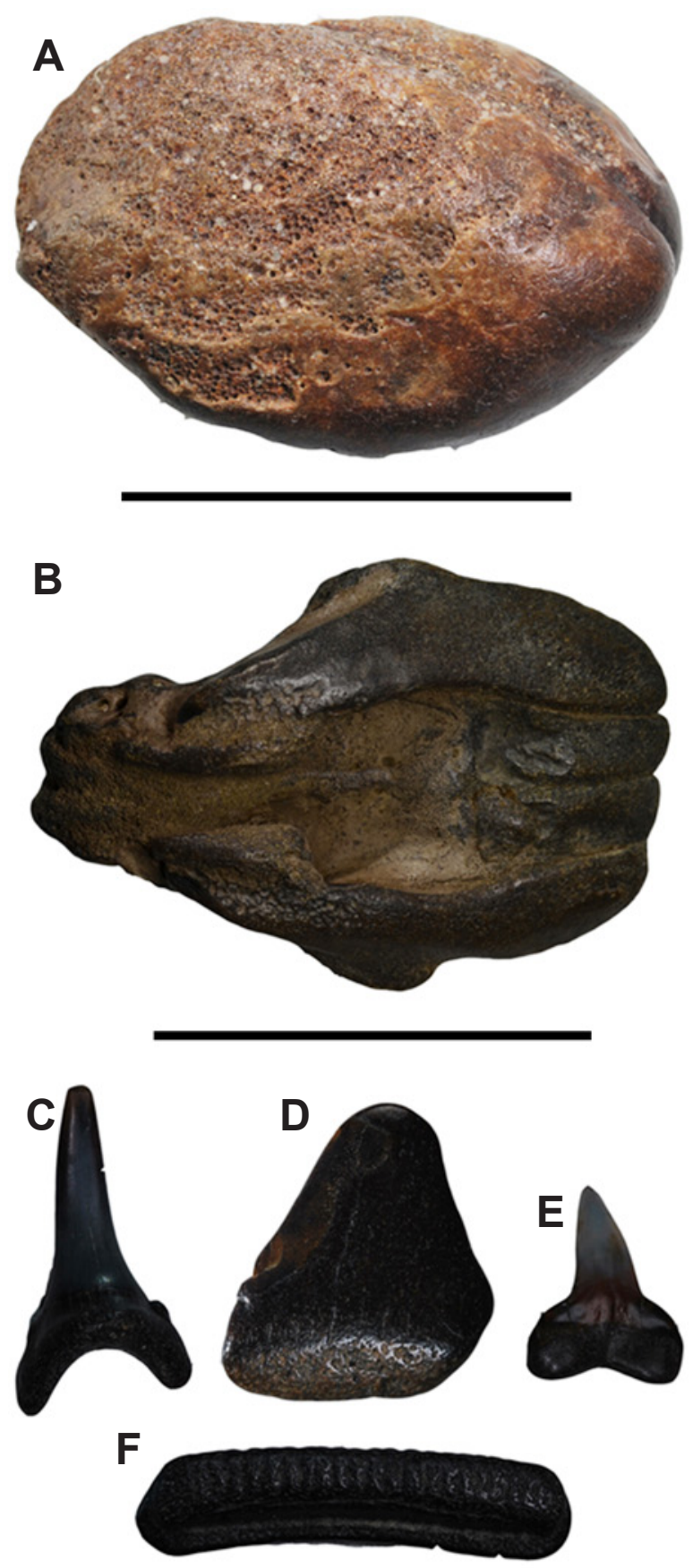

Figure 9. A-F, skeletal remains of the marine fauna. A, bone tumor of Sciaenidae indet. (MCN-PV 36.619); B, partial skull of Pontoporia sp. (MCN-PV 36.620); C-F, teeth of elasmobranchs; C, sand tiger shark Carcharias taurus (MCN-PV 36.621); D, white shark Carcharodon carcharias (MCN-PV 36.622); E, ground shark Carcharhinus sp. (MCN-PV 36.623); F, ray Myliobatiformes (MCN-PV 36.624) (by Erick Cruz). Scale bars $=50 \mathrm{~mm}$.

Lopes \& Buchmann, 2010). Similarly, the skeletal remains of marine fauna were preserved in these fluvial channels and lagoons when the continental shelf was occupied by marine environments during the sea-level rise.

Cecilio (2015) has shown the presence of submerged elevations and depressions on the shoreface and inner continental shelf and their interaction with the waves. While in the central sector the waves reach the beach with stronger energy due to the steeper and continuous slope of the shoreface and inner continental shelf, in the southern sector the waves reach the beach with decreased energy due to the elevations and depressions. The 60,80 and $100 \mathrm{~m}$ isobaths are situated further from the coast in the southern sector, which indicates that the decreasing of energy begins much sooner than in the central sector (Figure 12). Notwithstanding that the central sector has much more wave energy and therefore should be able to transport more fossils, the southern sector has more fossils collected and therefore indicates greater source-area availability.

A correlation exists between the morphology of the continental shelf and the coastline configuration. Along coastal embayments the shelf is wider and more gently sloping, whilst along coastal projections (e.g. Conceição and Hermenegildo) it is narrower and steeper (Dillenburg et al., 2000). The above longshore differences have determined the existence of gradients in wave height/energy along the coast (Dillenburg et al., 2003; Martinho, 2008). The wave power, measured by wave height/energy and the angle of wave attack (Swift, 1976), is higher on coastal projections (Lima et al., 2001; Martinho, 2008; Cecilio, 2015). There is strong evidence that the temporal long-term coexistence of regressive and transgressive barriers along the RS coast could be a product of the existence of longshore gradients in wave power (Dillenburg et al., 2009). Also, this gradient may hold the evidence of how the submerged fossiliferous deposits have changed over time and why the deposition of Pleistocene fossils in the backshore along the beaches of the CPRS is different.

Buchmann \& Tomazelli (2003) divided the submerged sedimentary rocks along the CPRS into three categories: (i) active submerged rocks are submitted directly to wave action, situated in the upper shoreface. It does not show biofouling, indicating recent exposure of the substrate and/or high sedimentary dynamic preventing the attachment of organisms due to severe abrasion. It can be found close to the 7-9 $\mathrm{m}$ isobaths (Parcel do Hermenegildo, Banco do Albardão and Banco Capela). In the current coastline adjacent to these submerged sedimentary rocks, it is found large amounts of mammalian fossils; (ii) intermediate submerged rocks are located in a transition zone in the lower shoreface/inner continental shelf where only seasonally storm waves interact with the bottom. It can be found close to the isobaths 14-17 m (Parcel do Carpinteiro, Banco Minuano, Parcel da Lagoa do Peixe and Parcel de Mostardas) and the isobaths 23-32 m (Parcel da Berta and deposits associated to the Banco do Albardão); (iii) passive submerged rocks correspond to the relic features that were reworked during the Last Great Transgression and which are no longer being reworked. It has little or none wave interaction with the bottom (offshore). There is no current sediment budget income, only biogenic contribution by biofouling and platform mud. It is located in the end of the transition zone and beyond, and there are records of the occurrence of mammalian fossils at depths of $40,70,90$ and $120 \mathrm{~m}$. 


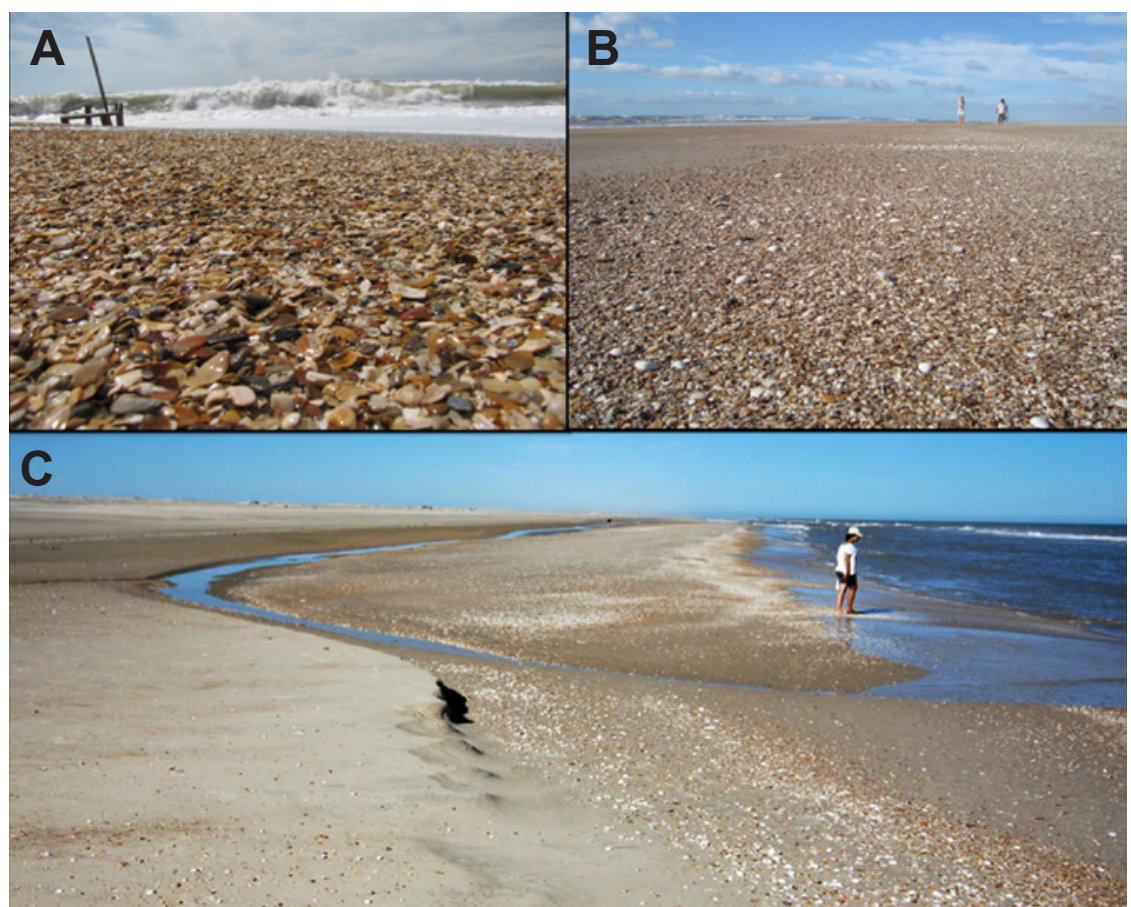

Figure 10. Concheiros beach in the southern sector of the coast with the presence of the thick konzentrat-lagerstätte of fossil marine shells. Notice how it has changed over the years, photos taken in 2006 (A) and 2008 (B) showing the massive presence of the marine shells deposited on the beach; and photo taken in 2013 (C) showing the decrease of them (by Francisco Buchmann).

Table 1. List of the terrestrial taxonomic groups identified for each sector with their respective percentage. Abbreviations: $\mathbf{X}$, presence; 0 , absence.

\begin{tabular}{|c|c|c|c|c|}
\hline \multirow{2}{*}{ Terrestrial Fauna } & \multicolumn{2}{|c|}{ Sectors } & \multirow{2}{*}{$\mathrm{N}$} & \multirow{2}{*}{$(\%)$} \\
\hline & Central & Southern & & \\
\hline \multicolumn{5}{|l|}{ MAMMALIA } \\
\hline Cingulata & $\mathrm{X}$ & $\mathrm{X}$ & \multirow{9}{*}{204} & \multirow{9}{*}{70} \\
\hline Glyptodontidae & $\mathrm{X}$ & $\mathrm{X}$ & & \\
\hline Glyptodon Owen, 1845 & $\mathrm{X}$ & $\mathrm{X}$ & & \\
\hline Panochthus Burmeister, 1872 & $X$ & $X$ & & \\
\hline Pampatheriidae & $\mathrm{X}$ & $\mathrm{X}$ & & \\
\hline Pampatherium Ameghino, 1875 & $\mathrm{X}$ & $X$ & & \\
\hline Holmesina Simpson, 1930 & 0 & $\mathrm{X}$ & & \\
\hline Dasypodidae & 0 & $X$ & & \\
\hline Propraopus Ameghino, 1881 & 0 & $X$ & & \\
\hline Artiodactyla & 0 & $X$ & \multirow{2}{*}{29} & \multirow{2}{*}{9} \\
\hline Cervidae indet. & 0 & $X$ & & \\
\hline Pilosa indet. & $X$ & $X$ & 25 & 8 \\
\hline Notoungulata & $X$ & $X$ & \multirow{3}{*}{21} & \multirow{3}{*}{7} \\
\hline Toxodontidae Owen, 1845 & $\mathrm{X}$ & $X$ & & \\
\hline Toxodon Owen, 1838 & $X$ & $\mathrm{X}$ & & \\
\hline Proboscidea & 0 & $\mathrm{X}$ & \multirow{2}{*}{8} & \multirow{2}{*}{3} \\
\hline Gomphotheriidae indet. & 0 & $\mathrm{X}$ & & \\
\hline Perissodactyla & 0 & $X$ & & \\
\hline Equidae & 0 & $X$ & 4 & 2 \\
\hline Equus Linnaeus, 1758 & 0 & $\mathrm{X}$ & & \\
\hline AVES indet. & 0 & $\mathrm{X}$ & 2 & 1 \\
\hline
\end{tabular}

Table 2. List of the marine taxonomic groups identified for each sector with their respective percentage. Abbreviations: $\mathbf{X}$, presence; $\mathbf{0}$, absence.

\begin{tabular}{|c|c|c|c|c|}
\hline \multirow{2}{*}{ Marine Fauna } & \multicolumn{2}{|c|}{ Sectors } & \multirow{2}{*}{$\mathrm{N}$} & \multirow{2}{*}{$(\%)$} \\
\hline & Central & Southern & & \\
\hline \multicolumn{5}{|l|}{ ACTINOPTERYGII } \\
\hline Perciformes & $\mathrm{X}$ & $\mathrm{X}$ & \multirow{2}{*}{46} & \multirow{2}{*}{40} \\
\hline Sciaenidae indet. & $\mathrm{X}$ & $\mathrm{X}$ & & \\
\hline \multicolumn{5}{|l|}{ REPTILIA } \\
\hline \multicolumn{5}{|l|}{ Testudines indet. } \\
\hline \multicolumn{5}{|l|}{ CHONDRICHTHYES } \\
\hline Lamniformes & 0 & $\mathrm{X}$ & \multirow{5}{*}{17} & \multirow{5}{*}{15} \\
\hline Odontaspididae & 0 & $\mathrm{X}$ & & \\
\hline Carchariastaurus Rafinesque, 1810 & 0 & $\mathrm{X}$ & & \\
\hline Lamnidae & 0 & $\mathrm{X}$ & & \\
\hline Carcharodon carcharias Linnaeus, 1758 & 0 & $\mathrm{X}$ & & \\
\hline Carcharhiniformes & 0 & $\mathrm{X}$ & \multirow{2}{*}{1} & \multirow{2}{*}{1} \\
\hline Carcharhinidae & 0 & $\mathrm{X}$ & & \\
\hline Myliobatiformes & 0 & $\mathrm{X}$ & 9 & 8 \\
\hline \multicolumn{5}{|l|}{ MAMMALIA } \\
\hline Artiodactyla & $\mathrm{X}$ & $\mathrm{X}$ & \multirow{4}{*}{16} & \multirow{4}{*}{14} \\
\hline Mysticeti indet. & $\mathrm{X}$ & $\mathrm{X}$ & & \\
\hline Pontoporiidae & 0 & $\mathrm{X}$ & & \\
\hline Pontoporia Gray, 1846 & 0 & $\mathrm{X}$ & & \\
\hline
\end{tabular}


Table 3. List of the terrestrial skeletal elements identified for each sector with their respective percentage. Abbreviations: X, presence; $\mathbf{0}$, absence.

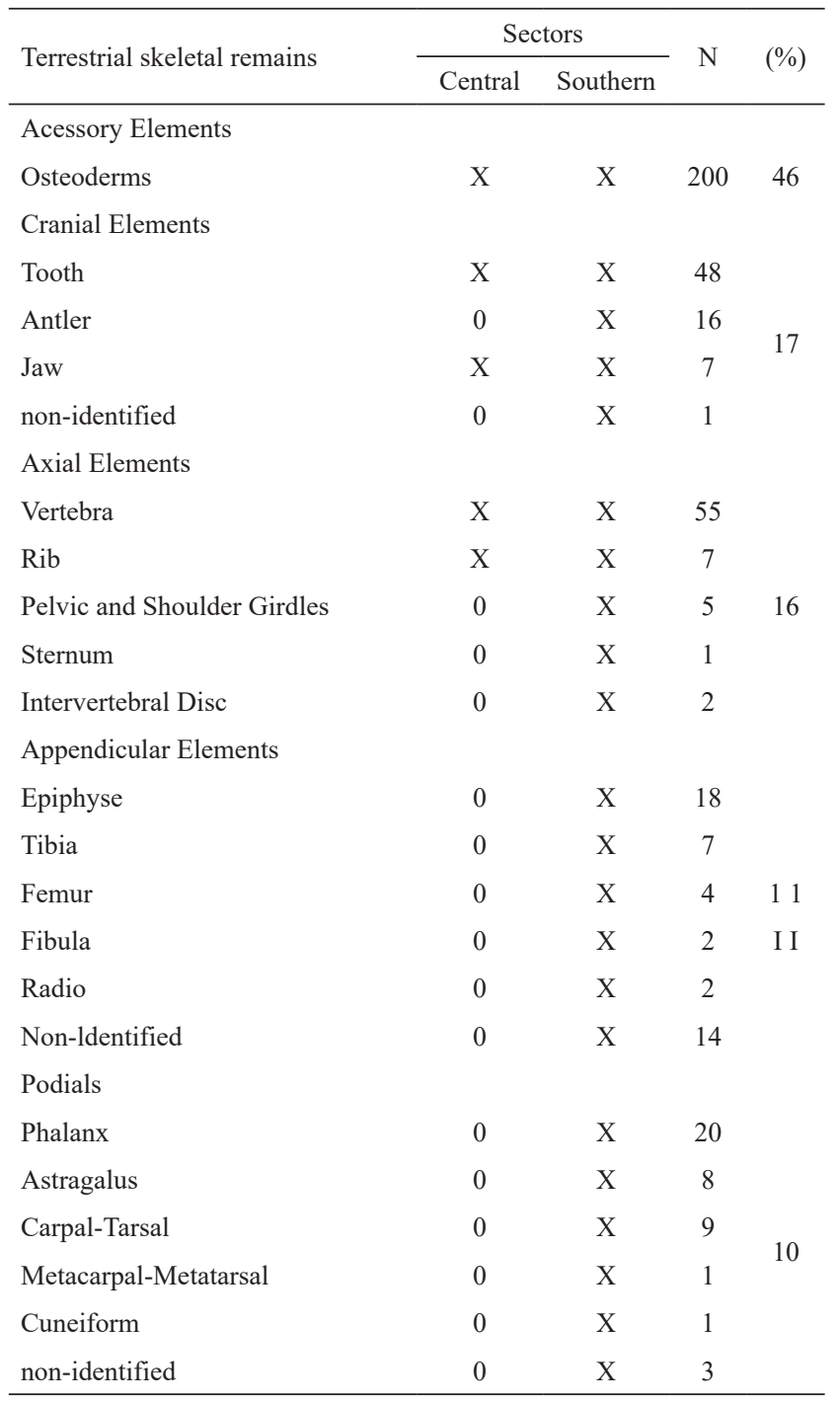

Table 4. List of the marine skeletal remains identified for each sector with their respective percentage. Abbreviations: $\mathbf{X}$, presence; $\mathbf{0}$, absence.

\begin{tabular}{|c|c|c|c|c|}
\hline \multirow{2}{*}{ Marine skeletal remains } & \multicolumn{2}{|c|}{ Sectors } & \multirow{2}{*}{$\mathrm{N}$} & \multirow{2}{*}{$(\%)$} \\
\hline & Central & Southern & & \\
\hline Tooth & 0 & $X$ & 24 & 28 \\
\hline Hyperostotic bone & $\mathrm{X}$ & $\mathrm{X}$ & 27 & 31 \\
\hline Operculum & $\mathrm{X}$ & $\mathrm{X}$ & 9 & 10 \\
\hline Plastron & $\mathrm{X}$ & $\mathrm{X}$ & 9 & 10 \\
\hline Pteryqiophore & 0 & $\mathrm{X}$ & 7 & 8 \\
\hline Vertebra & $\mathrm{X}$ & $\mathrm{X}$ & 4 & 5 \\
\hline Intervertebral disc & 0 & $\mathrm{X}$ & 2 & 2 \\
\hline Scale & 0 & $\mathrm{X}$ & 2 & 2 \\
\hline Tympanic Bullae & 0 & $\mathrm{X}$ & 1 & 1 \\
\hline Skull & 0 & $\mathrm{X}$ & 1 & 1 \\
\hline Blowhole & 0 & $\mathrm{X}$ & 1 & 1 \\
\hline
\end{tabular}
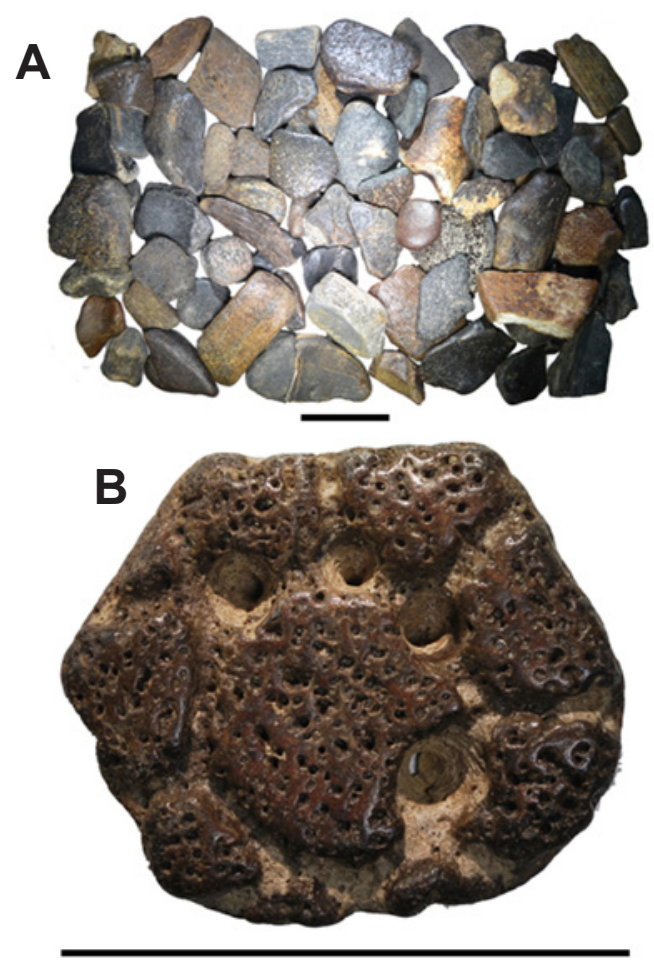

Figure 11. A-B, bioclasts population. A, non-identified fossils with high degree of fragmentation and abrasion by transport, losing diagnostic structures used for identification; B, identified fossil represented by an osteoderm of Glyptodon sp. (MCN-PV 36.600) with low degree of fragmentation and abrasion, preserving diagnostic structures used for identification (by Erick Cruz). Scale bars $=50 \mathrm{~mm}$.

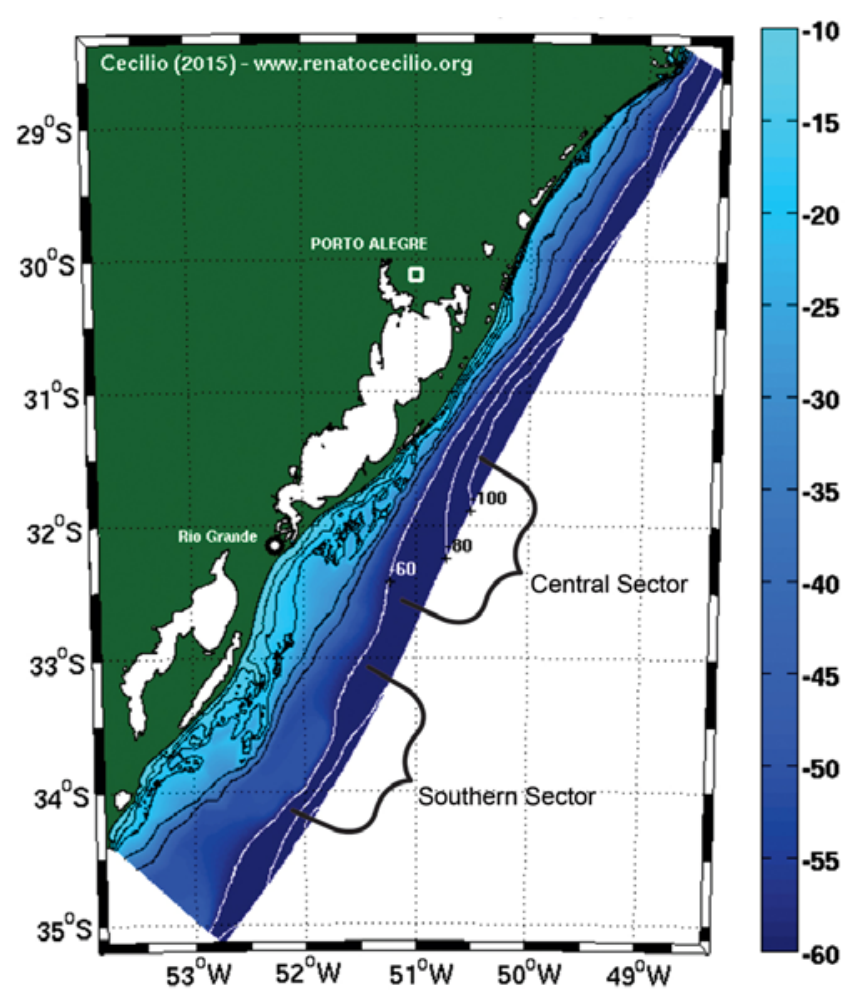

Figure 12. Southern Brazilian Shelf grid bathymetry $(\mathrm{m})$ showing the position of the 60,80 and $100 \mathrm{~m}$ isobaths. Notice the distant position from the coast of these isobaths in the southern sector when compared to the central sector (modified from Cecilio, 2015). 
The submerged sedimentary rocks are constituted essentially by carbonate rocks (strongly cemented beach rocks or coquinas) and are sometimes covered by corals (Oculina patagonica Angelis, 1908 and Astrangia rathbuni Vaughan, 1906), bryozoans, sponges, polychaete worms, crustaceans and coralline algae. O. patagonica dating showed an age superior to $40 \mathrm{ka}$, exceeding the ${ }^{14} \mathrm{C}$ method limit, and hence it was referred as Pleistocene. In the Parcel do Carpinteiro, the species A. rathbuni was collected in situ and it is also found along the CPRS in colonies which were reworked by storm waves (Buchmann et al., 2001a). Although strongly cemented by calcium carbonate and essentially composed of marine shells, the submerged sedimentary rocks exposed to wave attack also provide fossils of terrestrial and marine vertebrates associated with beachrocks and coquinas (Figure 13A) (Buchmann $\&$ Tomazelli, 2003). The presence of beach rocks and coquinas associated with mammalian fossils adduces its erosion from the shoreface and inner shelf, and reworking by waves (Figure 13B). The biofouling by corals, bryozoans, polychaete worms, barnacles and oysters present in these fossils adduces its exposure on the outer continental shelf (Figure 13C) (Buchmann, 2002; Lopes \& Buchmann, 2010). Besides submerged sedimentary rocks, several outcrops of semi-consolidated sediments (Pleistocene and Holocene) can be seen along the Rio Grande do Sul beaches, especially after storms events when the waves and currents rework the beach, remove the recent sandy covering and expose part of the antecedent substrate (Buchmann, 2002). According to Buchmann (2002), the Pleistocene beach rock outcrops found near the Conceição lighthouse (central sector) showed a Termoluminescence age of $109 \mathrm{ka}$ and was correlated to the Barrier-Lagoon Depositional System 3 proposed by Villwock et al. (1986). Also in the central sector, Holocene deposits of peat and mud associated with shells found on the adjacent beaches of the Peixe Lagoon showed a ${ }^{14} \mathrm{C}$ age of $3.6 \mathrm{ka}$. In the southern sector, Holocene deposits of muddy sand with organic matter found on the adjacent beaches of Hermenegildo and Chuí Creek showed a ${ }^{14} \mathrm{C}$ age of $38 \mathrm{ka}$ (Buchmann, 2002).

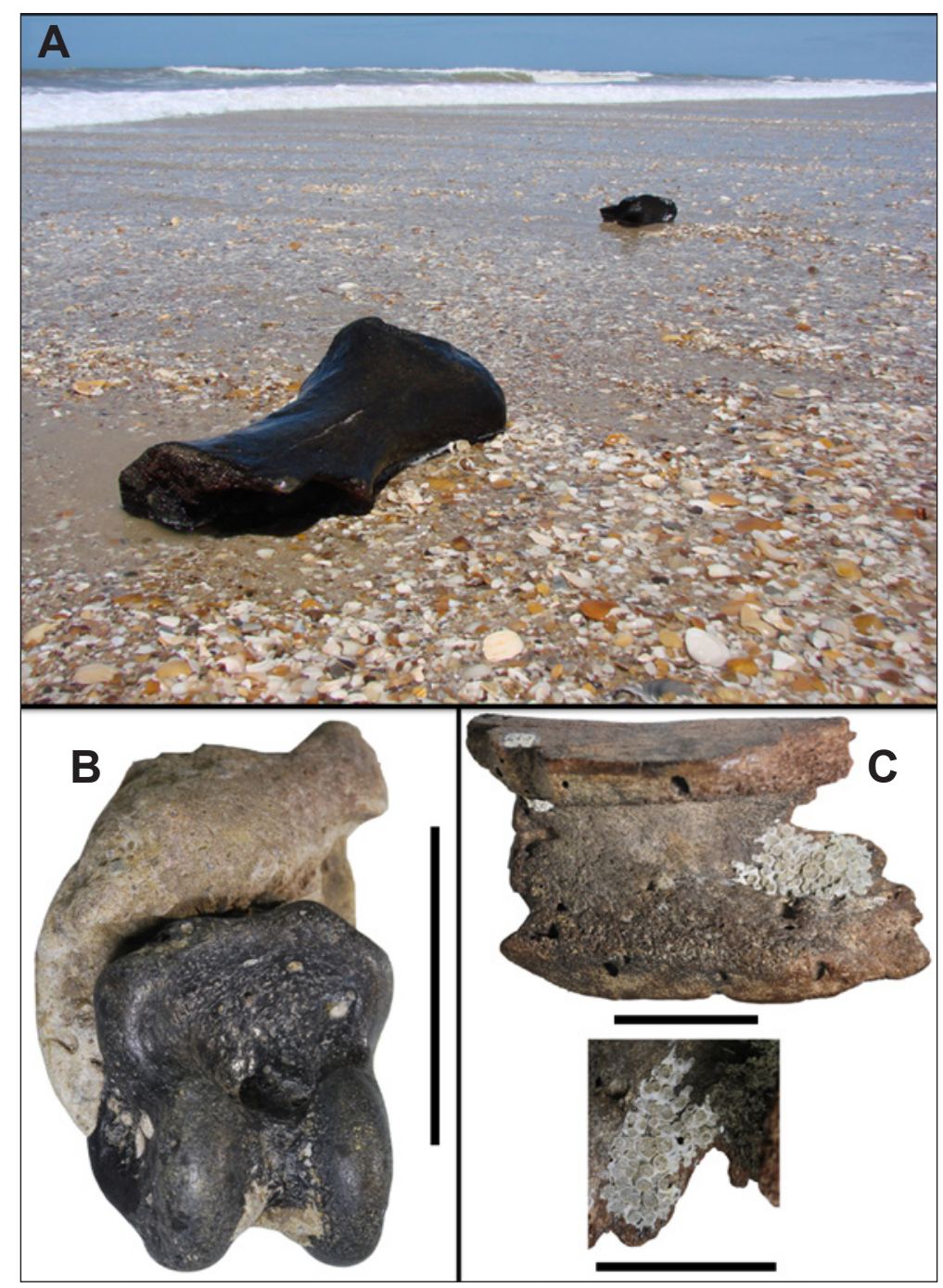

Figure 13. A-C, fossils of marine shells and land mammals thrown onto the beach by waves. $\mathbf{A}$, fossil of land mammal transported by waves onto the backshore of the Concheiros beach; B, sloth phalange associated with beachrock (MCN-PV 36.601); C, biofouling by coral (Astrangia sp.) on a fossil of land mammal (MCN-PV 36.602) (by Erick Cruz). Scale bars $=50 \mathrm{~mm}$. 


\section{Representativity of taxonomic groups and skeletal remains}

The skeletal remains were found disarticulated, exhibiting signs of abrasion by transport and most were incomplete, representing a mix of terrestrial and marine fauna. The southern sector had more skeletal remains and taxonomic groups identified maybe because it had also the largest amount of collected.

In the terrestrial fauna, the high percentage of osteoderms of cingulates can be explained by the large number of osteoderms that covers the skeleton of these animals and by the small size and compact shape of the osteoderms which favor the transport (Lopes et al., 2008; Aires \& Lopes, 2012; Cruz \& Buchmann, 2013b, 2015). In previous works (e.g. Aires \& Lopes, 2012) the same abundance was found for osteoderms of cingulates from Chuí Creek.

According to Moore (1994), teeth, vertebrae and ribs are structures found in greater quantity in the skeleton of mammals. In addition, Behrensmeyer (1975) said that skeletal elements carried by water currents are considered sediment particles, thus factors such as weight, shape and density are responsible for their transportability. Therefore, small-size (32-64 $\mathrm{mm}$ ) and compact-shape elements such as osteoderms, teeth and vertebrae are found in greater quantity and are easily transported. Bigger-sizes (exceeding $128 \mathrm{~mm}$ ) and blade/discshape elements, such as long bones are found in less quantity and are hardly transported (Voorhies, 1969; Frison \& Todd, 1986; Araújo et al., 2012; Aires \& Lopes, 2012). The difficulty of transporting bigger sized elements by the waves seems to be responsible for the low percentage of large cranial and postcranial remains of large-bodied taxa (Lopes et al., 2008; Aires \& Lopes, 2012; Cruz \& Buchmann, 2013b, 2015). The larger skeletal remains can be transported only by high energy waves, which occur only during extreme storms (Calliari et al., 1998b).

Among the cingulates, the predominance of Glyptodon (approx. 76\%) over other genera probably reflects the original diversity among these taxa (Aires \& Lopes, 2012). The presence of cingulates, cervids, gomphotheriids, ground sloths and toxodontids suggests open paleoenvironments such as prairies, steppes or savannas (Oliveira, 1999; Caron, 2004) with grasses, shrubs, wetlands and possibly gallery forests. This was also reinforced by analyses of stable isotopes $\left({ }^{13} \mathrm{C}\right.$ and ${ }^{18} \mathrm{O}$ ) in teeth of Toxodon and Stegomastodon (Lopes et al., 2013). The co-occurrence of fossils that indicates arid and open environments and other records that indicate permanently humid or forested environments, and also the lack of a stratigraphic context, made difficult paleocommunity reconstructions based on fossils from the continental shelf (Lopes et al., 2010; Aires \& Lopes, 2012).

In the marine fauna, the abundance of skeletal remains of fishes, such as pterygiophores, scales and vertebrae that were identified only in the southern sector probably reflects the dominance of fishes in the southern sector according to Buchmann (2002). Among the Lamniformes, the presence of Carcharias taurus probably reflects the original diversity of these taxa. The genus still lives in the south and southeast of the Brazilian coast (Richter, 1987). Furthermore, the presence of Carcharodon carcharias indicates a different paleoenvironment, since the genus is not found in the Brazilian coast nowadays (Buchmann \& Rincón Filho, 1997; Buchmann \& Tomazelli, 1999b).

Teeth of sharks and rays associated with the massive presence of the thick konzentrat-lagerstätte of fossil marine shells deposited in the foreshore and backshore of the beach has changed over the years (Figure 10). It seems that no new bioclasts are coming to the beach and the ones already there are being more and more fragmented into sand-sized grains and are being transported landward to the dune fields (Figure 14). The decrease of bioclasts deposition and the increasing fragmentation corroborate to the high percentage of small (32-64 mm) bioclasts and the hypothesis of the "source-area starvation" discussed above in the taphonomic characteristics section. This issue will be discussed further in another article.

\section{CONCLUSIONS}

Overall, both sectors seem to be under the same coastal hydrodynamics, which erodes and reworks the fossiliferous deposits and transports to the beach the skeletal remains and relic sediments associated. The great majority of the fossils underwent greater rework by waves while the minority is well preserved. Generally, small-size and compact-shape elements, such as osteoderms, teeth and vertebrae are found in greater quantity and are easily transported, and hence more prone to fragmentation.

Notwithstanding that the central sector has much more wave energy and therefore should be able to transport more fossils, the southern sector has more fossils collected and therefore indicates greater source-area availability. The presence of several submerged sedimentary rocks and records of paleolagoons and paleochannels on the shoreface and inner continental shelf of the southern sector indicates probably the source-areas where the skeletal remains were once fossilized and now are being eroded.

The fossils represent a mix of terrestrial and marine fauna. The same taxonomic groups and skeletal remains were identified in both sectors, except for some due to the different amount of fossils collected. Besides, the abundance of some taxonomic groups seem to be related to the original diversity, or to the small-size which favors the transport.

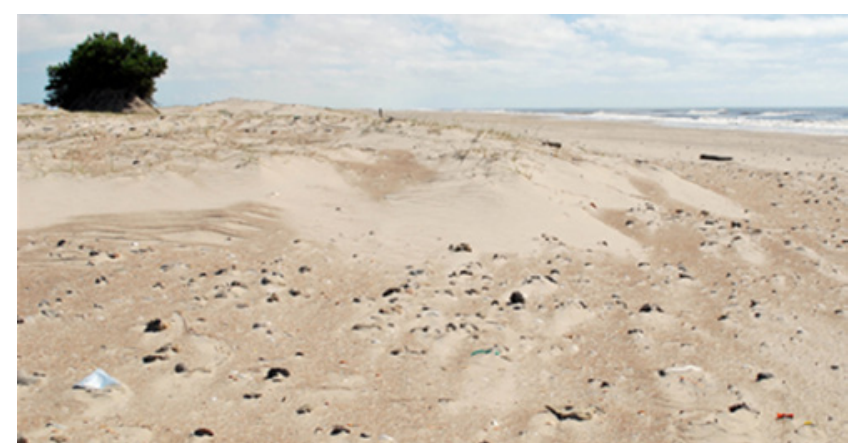

Figure 14. The presence of fossil marine shells fragmented into grains of sand covering the foredunes. Notice the darker sand composed of fragments of these shells over the quartz white sand (by Francisco Buchmann). 


\section{ACKNOWLEDGEMENTS}

In gratitude to my advisor S.R. Dillenburg for giving me the opportunity to carry on my research as his post-graduate student. To F. Buchmann for all the help, financial support in the field works and friendship. A special thanks for L. Rota, D. Loebmann and A.C. Giacometti Mai for the "camp-base" support and friendship. Part of this study was also possible by financial support of CAPES (scholarship grant for the author).

\section{REFERENCES}

Aires, A.S.S. \& Lopes, R.P. 2012. Representativity of Quaternary mammals from the southern Brazilian continental shelf. Revista Brasileira de Paleontologia, 15:57-66. doi:10.4072/rbp.2012.1.05

Angulo, R.J.; Giannini, P.C.F.; Suguio, K. \& Pessenda, L.C.R. 1999. The relative sea-level changes in the last 5,500 years sourthern Brazil (Laguna-Imbituba region, Santa Catarina state) based on vermetid 14c ages. Marine Geology, 159:323-339. doi:10.1016/ S0025-3227(98)00204-7

Angulo, R.J. \& Lessa, G.C. 1997. The Brazilian sea level curves: a critical review with emphasis on the curves from Paranaguá and Cananéia regions. Marine Geology, 140:141-166. doi:10.1016/ S0025-3227(97)00015-7

Angulo, R.J.; Lessa, G.C. \& Souza, M.C. 2006. A critical review of the mid- to late Holocene sea-level fluctuations on the eastern Brazilian coastline. Quaternary Science Reviews, 25:486-506. doi:10.1016/j.quascirev.2005.03.008

Araújo Jr., H.I.; Bissaro Jr., M.C.; Dos Santos, T.T.; Alves, R.S. \& Bergqvist, L.P. 2012. Tafonomia da megafauna pleistocênica brasileira: fluvial transport index (FTI) em análises de representatividade óssea. Revista Brasileira de Paleontologia, 15:95-104. doi:10.4072/rbp.2012.1.08

Behrensmeyer, A.K. 1975. The Taphonomy and paleoecology of Plio-Pleistocene vertebrate assemblages east of Lake Rudolf, Kenya. Bulletin of the Museum of Comparative Zoology, 146:474-574.

Buchmann, F.S.C. 1994. Distribuição dos fósseis pleistocênicos na zona costeira e plataforma continental interna no Rio Grande do Sul. Acta Geológica Leopoldensia, 17:355-364.

Buchmann, F.S.C. 2002. Bioclastos de organismos terrestres e marinhos na praia e plataforma interna do rio grande do sul: natureza, distribuição, origem e significado geológico. Programa de Pós-Graduação em Geociências, Universidade Federal do Rio Grande do Sul, Ph.D. thesis, 120 p.

Buchmann, F.S.C.; Barletta, R.C.; Tomazelli, L.J. \& Barreto, A.M.F. 1999. Novo afloramento pleistocênico na atual linha de costa do Rio Grande do Sul, Brasil. In: CONGRESSO DAASSOCIAÇÃO BRASILEIRA DE ESTUDOS DO QUATERNÁRIO, 7, 1999. Anais, Porto Alegre, 2 p.

Buchmann, F.S.C.; Caron, F.; Lopes, R.P.; Ugri, A. \& Lima, L.G. 2009. Panorama geológico da Planície Costeira do Rio Grande do Sul. In: A.M. Ribeiro; S.G. Bauermann \& C.S. Scherer (eds.) Quaternário do Rio Grande do Sul-integrando conhecimentos, Porto Alegre, Sociedade Brasileira de Paleontologia, p. 35-56 (Monografias 1).

Buchmann, F.S.C.; Pires, D.O.; Alves, F.N.A. \& Tomazelli, L.J. 2001a. Corais fósseis do Pleistoceno e corais recentes na costa do Rio Grande do Sul. In: CONGRESSO DA ASSOCIAÇÃO BRASILEIRA DE ESTUDOS DO QUATERNÁRIO, 8, 2001. Anais, Imbé, p. 75.
Buchmann, F.S.C. \& Rincón Filho, G. 1997. Fósseis de vertebrados marinhos do Pleistoceno Superior na porção sul da planície costeira do Rio Grande do Sul, Brasil. Notas Técnicas, 10:7-16.

Buchmann, F.S.C.; Seeliger, M.; Zanella, L.R.; Madureira, L.S.P.; Tomazelli, L.J. \& Calliari, L.J. 2001b. Análise batimétrica e sedimentológica no estudo do Parcel do Carpinteiro, uma paleolinha de praia pleistocênica na antepraia do Rio Grande do Sul, Brasil. Revista Pesquisas em Geociências, 28:109-115.

Buchmann, F.S.C. \& Tomazelli, L.J. 1999a. Fósseis da megafauna terrestre coletados na plataforma continental interna, RS, Brasil, e sua relação com a dinâmica costeira passada e atual. In: CONGRESSO DAASSOCIAÇÃO BRASILEIRADE ESTUDOS DO QUATERNÁRIO, 7, 1999. Anais, Porto Seguro, 3 p.

Buchmann, F.S.C. \& Tomazelli, L.J. 1999b. Ocorrência de fósseis de tubarão branco (Carcharodon carcharias) na porção sul e central da planície costeira do rio grande do sul, Brasil: considerações paleoclimáticas. In: CONGRESSO DA ASSOCIAÇÃO BRASILEIRA DE ESTUDOS DO QUATERNÁRIO, 7, 1999. Anais, Porto Seguro, 2 p.

Buchmann, F.S.C. \& Tomazelli, L.J. 2000. Altos topográficos submersos (parcéis) na antepraia do Rio Grande do Sul, Brasil, e sua influência na morfologia e dinâmica praial. In: SIMPÓSIO BRASILEIRO SOBRE PRAIAS ARENOSAS, 1, 2000. Anais, Itajaí, p. 174.

Buchmann, F.S.C. \& Tomazelli, L.J. 2001. A influência do substrato pré-holocênico na distribuição dos bioclastos carbonáticos ao longo da linha de costa (pós-praia) do Rio Grande do Sul. In: CONGRESSO DA ASSOCIAÇÃO BRASILEIRA DE ESTUDOS DO QUATERNÁRIO, 8, 2001. Anais, Imbé, p. 58-59.

Buchmann, F.S.C. \& Tomazelli, L.J. 2003. Relict nearshore shoals of Rio Grande do Sul, southern Brazil: origin and effects on nearby modern beaches. Journal of Coastal Research, 35:318-322.

Calliari, L.J.; Speranski, N. \& Boukareva, I. 1998a. Stable focus of wave rays as a reason of local erosion at the southern Brazilian coast. Journal of Coastal Research, 26:19-23.

Calliari, L.J.; Tozzi, H.M. \& Klein, A.H. 1998b. Beach morphology and coastline erosion associated with storm surges in southern Brazil, Rio Grande to Chuí, RS. Anais da Academia Brasileira de Ciências, 70:231-247.

Caron, F. 2004. Aspectos taxonômicos e tafonômicos dos fósseis de vertebrados terrestres (megafauna pampeana extinta) $e$ marinhos (peixes e cetáceos) da Praia do Cassino, RS. Curso de Graduação em Oceanologia, Universidade Federal do Rio Grande, Undergraduate monography, 129 p.

Caron, F.; Tomazelli, L.J.; Dehnhardt, B.A.; Medeanic, S. \& Dillenburg, S.R. 2007. A transgressão marinha pós-glacial na região de desembocadura do Arroio Chuí, planície costeira do Rio Grande do Sul: implicações paleogeográficas. In: CONGRESSO DA ASSOCIAÇÃO BRASILEIRA DE ESTUDOS DO QUATERNÁRIO, 11, 2007. Livro de resumos, Belém, p. 6.

Caron, F.; Tomazelli, L.J.; Lima, L.G.; Barboza, E.G.; Rosa, M.L.C.C. \& Dillenburg, S.R. 2011. Características estratigráficas da barreira transgressiva holocênica na praia dos Concheiros, planície costeira do Rio Grande do Sul, Brasil. In: CONGRESSO DA ASSOCIAÇÃO BRASILEIRA DE ESTUDOS DO QUATERNÁRIO, 13, 2011. Anais, Búzios, p. 107-111.

Cecilio, R.O. 2015. An ocean wind-wave climatology for the Southern Brazilian shelf. Programa de Pós-Graduação em Geociências, Universidade Federal do Rio Grande do Sul, Ph.D. thesis, $116 \mathrm{p}$. 
Corrêa, I.C.S. 1986. Evidence of sea level fluctuation on the Rio Grande do Sul continental shelf, Brazil. Quaternary of South America and Antarctic Peninsula, 40:237-249.

Corrêa, I.C.S. 1990. Analyse Morphostructurale et Evolution Paleogeographique de La Plate-Forme Continentale Atlantique Sudbresilienne (Rio Grande Do Sul - Bresil). Universite de Bourdeaux I, Ph.D. thesis, $314 \mathrm{p}$.

Corrêa, I.C.S. 1994. Interpretation morphostructurale de la plateforme continentale du Rio Grande do Sul, a partir de l'Analise Cartographique. Notas Técnicas, 7:3-26.

Corrêa, I.C.S.; Martins, L.R.S.; Ketzer, J.M.M.; Elias, A.R.D. \& Martins, R. 1996. Evolução sedimentológica e paleogeográfica da plataforma continental sudeste e sul do Brasil. Notas Técnicas, 9:51-61.

Cruz, E.A. \& Buchmann, F.S.C. 2013a. Retrabalhamento praial em fósseis da megafauna, RS. In: CONGRESSO DAASSOCIAÇÃO BRASILEIRA DE ESTUDOS DO QUATERNÁRIO, 15, 2013. Resumos, Natal, 1 p.

Cruz, E.A. \& Buchmann, F.S.C. 2013b. Tafonomia e taxonomia dos bioclastos encontrados na praia dos Concheiros, RS. In: CONGRESSO BRASILEIRO DE PALEONTOLOGIA, 23, 2013. Boletim de Resumos, Gramado, p. 303-304.

Cruz, E.A. \& Buchmann, F.S.C. 2015. Representatividade dos fósseis de mamíferos pleistocênicos no extremo sul do Brasil. In: CONGRESSO DA ASSOCIAÇÃO BRASILEIRA DE ESTUDOS DO QUATERNÁRIO, 15, 2015. Anais, Imbé, p. $136-137$.

Cruz, E.A.; Dillenburg, S.R. \& Buchmann, F.S.C. 2015a. Variação quanti-qualitativa dos fósseis pleistocênicos nos setores centro e sul da planície costeira do Rio Grande do Sul. In: CONGRESSO DA ASSOCIAÇÃO BRASILEIRA DE ESTUDOS DO QUATERNÁRIO, 15, 2015. Anais, Imbé, p. 138-139.

Cruz, E.A.; Dillenburg, S.R. \& Buchmann, F.S.C. 2015 b. Comparação dos fósseis pleistocênicos encontrados nos setores centro e sul da planície costeira do Rio Grande do Sul. In: SEMANA ACADÊMICA DOS PÓS-GRADUANDOS DO INSTITUTO DE GEOCIÊNCIAS DA UFRGS, 1, 2015. Resumos, Porto Alegre, $1 \mathrm{p}$.

Dillenburg, S.R. 1994. O potencial de preservação dos registros sedimentares do Sistema Deposicional Laguna/Barreira IV na costa do Rio Grande do Sul. Notas Técnicas, 9:1-11.

Dillenburg, S.R. 1996. Oscilações holocênicas do nível relativo do mar registradas na sucessão de fácies lagunares na região da laguna de Tramandaí, RS. Revista Pesquisas em Geociências, 23:17-24.

Dillenburg, S.R.; Barboza, E.G.; Tomazelli, L.J.; HESP, P.A.; Clerot, L.C.P. \& Ayup-Zouain, R.N. 2009. The Holocene coastal barriers of Rio Grande do Sul. In: S.R. Dillenburg \& P.A. Hesp (eds.) Geology and Geomorphology of Holocene Coastal Barriers of Brazil, Springer, p. 53-91.

Dillenburg, S.R.; Roy, P.S.; Cowell, P.J. \& Tomazelli, L.J. 2000. Influence of antecedent topography on coastal evolution as tested by the Shoreface Translation Barrier Model (STM). Journal of Coastal Research, 16:71-81.

Dillenburg, S.R.; Tomazelli, L.J. \& Barboza, E.G. 2004. Barrier evolution and placer formation at Bujuru southern Brazil. Marine Geology, 203:43-56. doi:10.1016/S0025-3227(03)00330-X

Dillenburg, S.R.; Tomazelli, L.J. \& Clerot, L.C.P. 2003. Gradients of wave energy as the main factor controlling the evolution of the coast of Rio Grande do Sul in southern Brazil during the Late Holocene. In: INTERNATIONAL SYMPOSIUM ON COASTAL ENGINEERING AND SCIENCE OF COASTAL PROCESS, 5, 2003. Proceedings, Clearwater, 9 p.
Figueiredo Jr., A.C. 1975. Geologia dos depósitos calcários biodetríticos da plataforma continental do Rio Grande do Sul. Programa de Pós-Graduação em Geociências, Universidade Federal do Rio Grande do Sul, M.Sc. thesis, 72 p.

Frison, G.C. \& Todd, L.C. 1986. The Colby Mammoth site: taphonomy and archaeology of A Clovis kill in Northern Wyoming. Albuquerque. Albuquerque, University of New Mexico Press, 238 p.

Imbrie, J.; Hays, J.D.; Martinson, D.G.; Mcintyre, A.; Mix, A.C.; Morley, J.J.; Pisias, N.G.; Prell, W.L. \& Shakleton, N.J. 1984. The orbital theory of Pleistocene climate: support from a revised chronology of marine $18 \mathrm{O}$ record. In: A.L. Berger; J. Imbrie; J. Hays; G. Kukla \& B. Saltzman (eds.) Milankovitch and climate, part 1., D. Reidel Publishing, p. 269-305.

Lima, S.F.; Almeida, L.E.S.B. \& Toldo Jr., E.E. 2001. Estimativa da capacidade do transporte longitudinal de sedimentos a partir de dados de ondas para a costa do Rio Grande do Sul. Revista Pesquisas em Geociências, 28:99-107.

Lima, L.G. \& Buchmann, F.S.C. 2005. Novo afloramento fossilífero (Pleistoceno/Holoceno) no sul da planície costeira do Rio Grande do Sul. In: CONGRESSO DA ASSOCIAÇÃO BRASILEIRA DE ESTUDOS DO QUATERNÁRIO, 10, 2005. Livro de Resumos, Rio de Janeiro, 7 p.

Lima, L.G.; Dillenburg, S.R.; Medeanic, S.; Barboza, E.G.; Rosa, M.L.C.C. \& Tomazelli, L.J. 2013. Sea-level rise and sediment budget controlling the evolution of a transgressive barrier in southern Brazil. Journal of South American Earth Sciences, 42:27-38. doi:10.1016/j.jsames.2012.07.002

Lopes, R.P. 2013. Biostratigraphy of the Pleistocene fossiliferous deposits of southern Brazilian coastal area. Journal of Mammalian Evolution, 20:69-82. doi: 10.1007/s10914-0119173-y

Lopes, R.P. \& Buchmann, F.S.C. 2010. Pleistocene mammals from the southern Brazilian continental shelf. Journal of South American Earth Sciences, 31:17-27. doi:10.1016/j. jsames.2010.11.003

Lopes, R.P.; Buchmann, F.S.C. \& Caron, F. 2008. Taphonomic analysis of Pleistocene mammals from deposits submerged along southern Rio Grande do Sul coastal plain, Brazil. Arquivos do Museu Nacional, 66:213-229.

Lopes, R.P.; Buchmann, F.S.C.; Caron, F. \& Itusarry, M.E.G.S. 2001. Tafonomia dos fósseis de vertebrados (megafauna extinta) encontrados ao longo das barrancas do Arroio Chuí e linha de costa, Rio Grande do Sul, Brasil. Revista Pesquisas em Geociências, 28:67-73.

Lopes, R.P.; Buchmann, F.S.C.; Caron, F. \& Itussary, M.E.G.S. 2009. Barrancas fossilíferas do Arroio Chuí, RS - importante megafauna pleistocênica no extremo sul do Brasil. In: M. Winge; C. Schobbenhaus; M. Berbert-Born; E.T. Queiroz; D.A. Campos; C.R.G. Souza \& A.C.S. Fernandes (eds.) Sítios Geológicos e Paleontológicos do Brasil, Serviço Geológico do Brasil, p. 355-362.

Lopes, R.P.; Dillenburg, S.R.; Schultz, C.L.; Ferigolo, J.; Ribeiro, A.M.; Pereira, J.C.; Holanda, E.C.; Pitana, V.G. \& Kerber, L. 2014a. The sea-level highstand correlated to marine isotope stage (MIS) 7 in the coastal plain of the state of Rio Grande do Sul, Brazil. Anais da Academia Brasileira de Ciências, 86:1573-1595. doi:10.1590/0001-3765201420130274

Lopes, R.P. \& Ferigolo, J. 2015. Post mortem modifications (pseudopaleopathologies) in Middle-Late Pleistocene mammal fossils from southern Brazil. Revista Brasileira de Paleontologia, 18:285-306. doi:10.4072/rbp.2015.2.09 
Lopes, R.P.; Kinoshita, A.; Baffa, O.; Figueiredo, A.M.G.; Dillenburg, S.R.; Schultz, C.L. \& Pereira, J.C. 2014b. ESR dating of Pleistocene mammals and marine shells from the coastal plain of Rio Grande do Sul state, southern Brazil. Quaternary International, 352:124-134. doi:10.1016/j.quaint.2013.07.020

Lopes, R.P; Oliveira, L.C.; Figueiredo, A.M.G.; Kinoshita, A.; Baffa, O. \& Buchmann, F.S.C. 2010. ESR dating Pleistocene mammal teeth and its implications for the biostratigraphy and geological evolution of the coastal plain, Rio Grande do Sul, southern Brazil. Quaternary International, 212:213-222. doi:10.1016/j. quaint.2009.09.018

Lopes, R.P. \& Pereira, J.C. 2010. Um novo sítio paleontológico na planície costeira do Rio Grande do Sul. In: SIMPÓSIO BRASILEIRO DE PALEONTOLOGIA DE VERTEBRADOS, 7, 2010. Resumos, Rio de Janeiro, p. 93.

Lopes, R.P. \& Pereira, J.C. 2013. Pleistocene mammalian fossils from the Mirim Lake, southern Brazil. In: CONGRESSO BRASILEIRO DE PALEONTOLOGIA, 23, 2013. Boletim de Resumos, Gramado, p. 243.

Lopes, R.P.; Ribeiro, A.M.; Dillenburg, S.R. \& Schultz, C.L. 2013. Late Middle to Late Pleistocene paleoecology and paleoenvironments in the coastal plain of Rio Grande do Sul state, southern Brazil, from stable isotopes in fossils of Toxodon and Stegomastodon. Palaeogeography, Palaeoclimatology, Palaeoecology, 369:385-394. doi:10.1016/j.palaeo.2012.10.042

Martin, L.; Dominguez, J.M.L. \& Bittencourt, A.C.S.P. 2003. Fluctuating Holocene sea levels in Eastern and Southeastern Brazil: evidence from multiple fossil and geometric indicators. Journal of Coastal Research, 19:101-124.

Martin, L.; Suguio, K. \& Flexor, J.M. 1979. Le Quaternaire marin du littoral brésilien entre Cananéia (SP) et Barra de Guaratiba (RJ). In: INTERNATIONAL SYMPOSIUM ON COASTAL EVOLUTION IN THE QUATERNARY, 1, 1979. Proceedings, São Paulo, p. 296-331.

Martinho, C.T. 2008. Morfodinâmica e evolução de campos de dunas transgressivos quaternários do litoral do Rio Grande do Sul. Programa de Pós-Graduação em Geociências, Universidade Federal do Rio Grande do Sul, Ph.D. thesis, 241 p.

Martins, L.R.; Urien, C.M.; Corrêa, I.C.S. \& Martins, I.R. 1996. Late Quaternary processes along the Rio Grande do Sul continental shelf (southern Brazil). Notas Técnicas, 9:62-68.

Moore, K.L. 1994. Anatomia orientada para a clínica. $1^{\mathrm{a}} \mathrm{ed}$. Rio de Janeiro, Guanabara Koogan, 831 p.

Oliveira, E.V. 1999. Quaternary vertebrates and climates of southern Brazil. In: J. Rabassa \& M. Salemme (eds.) Quaternary of South America and Antarctic Peninsula, A.A. Balkema Publishers, p. 61-73.
Paula Couto, C. 1975. Mamíferos fósseis do Quaternário do sudeste brasileiro. Boletim Paranaense de Geociências, 33:89-132.

Paula Couto, C. 1979. Tratado de Paleomastozoologia. Rio de Janeiro, Academia Brasileira de Ciências, 563 p.

Silva, J.L.B. 2009. Identificação do sistema de paleodrenagem na margem continental sul brasileira adjacente à Lagoa Mirim no Terciário Superior por sísmica de reflexão. Programa de Pós-Graduação em Geociências, Universidade Federal do Rio Grande do Sul, Ph.D. thesis, 215 p.

Soliani Jr., E. \& Jost, H. 1974. Mamíferos pleistocênicos e sua posição estratigráfica na planície costeira do Rio Grande do Sul, SE do Brasil. In: CONGRESO ARGENTINO DE PALEONTOLOGÍA Y BIOESTRATIGRAFÍA, 1, 1974. Actas, Tucumán, p. 569-574.

Swift, D.J.P. 1976. Continental shelf sedimentation. In: D.J. Stanley \& D.J.P. Swift (eds.) Marine sediment transport and environmental management, John Wiley \& Sons, p. 311-350.

Tomazelli, L.J. \& Dillenburg, S.R. \& Villwock, J.A. 2000. Late Quaternary geological history of Rio Grande do Sul coastal plain, southern Brazil. Revista Brasileira de Geociências, 30:470-472.

Tomazelli, L.J., Villwock, J.A. 1996. Quaternary geological evolution of Rio Grande do Sul coastal plain, southern Brazil. Anais da Academia Brasileira de Ciências, 68:373-382.

Villwock, J.A. 1984. Geology of the Coastal Province of Rio Grande do Sul, southern Brazil: a synthesis. Revista Pesquisas em Geociências, 16:5-49.

Villwock, J.A. \& Tomazelli, L.J. 1995. Geologia costeira do Rio Grande do Sul. Notas Técnicas, 8:1-45.

Villwock, J.A.; Tomazelli, L.J.; Loss, E.L.; Dehnhardt, E.A,; Horn, N.O.; Bachl, F.A. \& Dehnhardt, B.A. 1986. Geology of the Rio Grande do Sul Coastal Province. In: J. Rabassa (ed.) Quaternary of the South America and Antarctic Peninsula, A.A. Balkema Publishers, p. 79-97.

Voorhies, M.R. 1969. Taphonomy and population dynamics of an Early Pliocene fauna, Knox County, Nebraska. University Wyoming Contributions to Geology Special Paper, 1:1-69.

Weschenfelder, J.; Baitelli, R.; Corrêa, I.C.S.; Bortolin, E.C. \& Santos, C.B. 2014. Quaternary incised valleys in southern Brazil coastal zone. Journal of South American Earth Sciences, 55:83-93. doi:10.1016/j.jsames.2014.07.004

Weschenfelder, J.; Corrêa, I.C.S.; Aliotta, S. \& Baitelli, R. 2010. Paleochannels related to Late Quaternary sea-level changes in southern Brazil. Brazilian Journal of Oceanography, 58:35-44. doi:10.1590/S1679-87592010000600005

Received in January, 2016; accepted in October, 2016. 